\title{
A Conceptual paper on Media Freedom: Comparing Islamic and Western Perspectives
}

\author{
Faiswal Kasirye \\ Department of Communication \\ International Islamic University Malaysia \\ Email: Kasirye.faiswal@gmail.com
}

\section{Introduction}

The term freedom can be generalized as doing something with your own will without any dictate in terms of independence, unrestricted as advanced by Peter (1976). There are several types of freedoms as enshrined in the Universal Declaration of Human Rights Charter (UDHR) (Assembly, 1948) that was penned on by the different governments in the world in respect of the people's rights. Therefore, it can be concluded that freedom also tantamount to free will.

Freedom is not just based on one human right, but rather a combination of several rights including; freedom of the press and freedom of speech which literally also fall under the generalization of freedom of expression. Therefore, freedom of the press under freedom of expression can be achieved under actions such as movies, writing books, audio visual communication in the media, singing, newspaper article writing and news writing and reporting on the happenings in the world using different media.

Since ancient days, freedom of speech and press there by called 'media' has been recognized although with the several developments that have come along, there are some restrictions that have been put on the media and the press freedom in general as penned by several western school of thought. Islamically, freedom of expression (speech and press) started all the way from the $6^{\text {th }}$ century where it gets its roots although several perspectives in the west dispute that history. In the west, the term freedom of expression is believed to have been introduced in the $18^{\text {th }}$ century (Donnelly, 2013).

\section{Media Freedom in the Islamic Perspective}

The concept of freedom of expression is granted but limited by the quran and the Sunna of the prophet (PBUH). In addition, Islam allows every individual to have undeniable free speech and expression to the best of their limits. However, the free speech is also not absolute whereby it has to be balanced with a person's personal life, dignity and personality-characters in order not to turn the freedom into an evil thing among the other people. 
Freedom of expression in the perspective of (speech and press) is a right, but also a very gigantic obligation too. Islam supports it because it's a human right that everyone deserves. People have a right to free speech if they are to air out their views without any restriction or coercion. In addition, Rafiq and Akhatar (2018) in their study on the freedom of speech in Islam and the international conventions contend that, "When people speak out their thoughts and mind, they bring out their moral values, therefore human speech should be within the limits of morality. Also, People use their right of free speech forgetting the responsibility that this freedom if used carelessly can hurt other's feelings" (p. 146).

Several ancient muslim scholars like (Mahmassani, 1979; Muhammed, 1963; AbdulHamid, 1974 and Kamali, 1997) refer to freedom of expression in the different perspective including freedom of religion, opinion, speech, thought, interpretation, all to represent the word freedom of expression as reported by Bhat (2014, p. 70-71). The scholars intimate that Islam as a religion accords individuals their ardent right to be exercised freely for as long as they do not infringe on other people's right to exercise their rights and dignity.

Al-Raysuni (2006) assert that, "Islam affords opportunity to every individual to express their opinion in accordance to public interests" (p. 27). Therefore, the primary aim of islamic sharia is to grant human beings their freedom and release them to do as they wish so long as they are exercising their freedoms with in the respected whims and accord others their dignity that they deserve, in a bid to serve the commandments of Allah as well as following the teaching of the prophet (PBUH) and Allah's commandments.

Scholars like Saeed and Ahmad (2013) intimate that, freedom of expression is every Muslim's obligation and does not just stop at expressing themselves because, it is enshrined in the quran although Allah puts some limitations to it I order to deter those that may be tempted to over exercise it and end up not respecting other people's rights and dignity. This in reality of today's media gives them a green light and indeed other people at large to exercise themselves so long as they do it with in the accepted limits that Allah prescribed in surat Al-Ahzaab where He said:

"O believers! Be mindful of Allah, and say what is right. He will bless your deeds for you, and forgive your sins. And whoever obeys Allah and His Messenger, has truly achieved a great triumph" (Quran, 33:70-71). 
In conclusion, there is logic in the exercise of the freedom of speech and press (expression) which talks about living in a certain society with tenable behaviour. In fact, Bhat (2014) argues that, "human kind in Islam is limited to only utter out their opinions when they are going to help or when their words are intended to helping another person in a bid to preserving peace and tranquility, so that people stay behind from social tribulations, pandemonium and muddle" (p. 71). However, such limits on freedom of speech and expression do not reduce one to not speaking the truth and engaging in degrade humanity as the core function of a media personnel is to speak the truth in whatever they are communicating to the public. On the aspect of speaking the truth always, Allah continues to stress it in Surat Yunus and says:

"That is Allah, your True Lord. So what is beyond the truth except falsehood? How can you then be turned away?" (Quran: 10:32).

\section{Media Freedom in the Western Perspective}

Voltmer (2014) stresses that, "press freedom in the west is as indeed any other democratic norm, a social construct that emerges from collective negotiations over its meaning, institutional form and practice" (p. 10). In addition, the scholar believes that, the way freedom of media in the west is looked at is like the only place or platform where free public exchange of opinions can happen and ideas are scrutinized among the publicists as they are delivered to the population. Some even call media freedom as the 'defining factor of democracy' because, a number of governments in the world recognize the media as the fourth estate and therefore, they base most of their decisions on the conduct of the media.

On the international scene, Article 19 of UNESCO Global Campaign for Free expression, highlights the general principles that were adopted by several western nations. some of these principles in regards to freedom of expression. These include; "Everyone has the right to hold opinions, expression, seek, receive and impart information and ideas although restricted on specific grounds......" (UNESCO, 2000).

Looking at the above principles, it can be concluded, that the west thrive more on the notion that freedom is an inalienable right that all human beings deserve. Therefore, freedom of speech as among the highlighted above should be of concern to every one if it is seen as not being accorded the right decorum it deserves because, the press, or the media is the backbone and the main source of information for the public. 
However, in his study, Bhat (2014) contends that, "the West claim for absolute freedom which is an impossibility on the side of Islam, as their actions contradict their own claim." The scholar cited an example of some Western countries that have banned the headscarf worn by women, which shows a conflict between the concept of religious freedom and concept of West on freedom of expression. Their approach towards the freedom of expression seems to still be in a developing position

Freedom of expression or speech means expression of ideas subject to the understanding that they do not, in turn, compel others into listening or that they do not invade others rights essential to the dignity of individuals. Vile et al. (2009) contend that in countries like the US, freedom of the media is in fact guaranteed by the First Amendment that is enshrined in the country's constitution. In fact, the scholars add that media in some states is also budgeted for in the national budget.

Scholars like Koltay (2019) notes in his study that, the speedy change in the way freedom of the media is portrayed now days has in some instances resulted into some journalists becoming victims of publishing wrong information because of random picking of the same from unverifiable sources but because its available for the taking especially from the different social media platforms that are frequented with a lot of fake news on a daily basis all over the world some have even faced courts for the same.

In the west, there is less media dictatorship either from the government or the ownership because they overly consider journalism as a public service job and not just to make money out of it. This is a little different with other countries outside the west. In the west, ownership changes, random dismissals in the newsrooms, random shifts in advertisements, friendly and less friendly calls from the respective governments to the editors of the respective media organizations is very low as according to Bieber (2018).

\section{Conclusion}

In conclusion, according to Freedom House's Freedom in the World data for 2020, media freedom has been deteriorating around the world over the past decade, with new forms of repression taking hold in open societies and authoritarian states alike, a trend that is acute in the west now days. With regards to Islamic perspective, there is a clear difference between the two perspective. The biggest one being, that the western allows everyone to disseminate any information whether truthful or not, but they believe that 
every individual has a right to do what they want provided they have the means. Contrasting that view with the islamic perspective, Islam allows the same rights to freedom of expression although with limitations to only speak out the truth alone as discussed in the previous section. In fact, Allah talks about punishing those that would come out to say untruthful things, yet as a muslim enjoying your rights to speech, you have to take cognizant of other people's rights to dignity and other rights.

\section{References}

Abd al-Hamid M (1974). Mabadi Nizam al-hukm fi'l-Islam, Alexandaria: Mansha'ah al-Ma'rif, p.230ff.

Al-Raysuni, A. (2006). Imam al-Shatibi's theory of the higher objectives and intents of Islamic law. The Other Press.

Assembly, U. G. (1948). Universal declaration of human rights. UN General Assembly, 302(2).

Bhat, A. M. (2014). Freedom of expression from Islamic perspective. Journal of Media and Communication Studies, 6(5), 69-77.

Bieber, F. (2018). Patterns of competitive authoritarianism in the Western Balkans. East European Politics, 34(3), 337-354.

Donnelly, J. (2013). Universal human rights in theory and practice. Cornell University Press.

Freedom of Expression, accessed November 27, 2020, from https://en.oxforddictionaries.com/definition/freedom of speech.

Kamali, M. H. (1997). Freedom of expression in Islam. Islamic Texts Society.

Koltay, A. (2019). The concept of media freedom today: new media, new editors and the traditional approach of the law. Journal of Media Law, 7(1), 36-64.

Mahmassani, S. (1979). Arkan Huquq al-Insan fi al-Islam. Beirut: Dâr al- 'llm li'lMalâyîn.

Muhammad KL (1963). Al-Nuzum al-Siyasiyyah (Cairo: Dr al-Fikr al- 'Arabi,),Wafi, huququl insan fil islam, Sayyid anasirul quwwah fil islam

Nordenstreng, K. (2016). Liberate (press) freedom from its ideological baggage! Les Enjeux de l'information et de la communication, (2), 157-161.

Peter D (1976). The American Heritage, Dell Publishing co. New York, p.215.

Rafiq, A., \& Akhatar, N. (2018). ENGLISH-FREEDOM OF SPEECH IN ISLAM AND IN INTERNATIONAL CONVENTIONS. The Scholar-Islamic Academic Research Journal, 4(2), 145-172.

Saeed, D., \& Ahmad, R. (2013). Quranic Concept of the Freedom of Expression: A Descriptive Study in Modern Socio-Political Perspective. Al-Qalam June.

UNESCO (2000). Principles on Freedom of Expression and Protection of Reputation, UNESCO, ARTICLE 19, London. http://www.ipu.org/splz-e/sfe/definition.pd.

Vile, J. R., Hudson Jr, D. L., \& Schultz, D. (2009, June). Encyclopedia of the First Amendment. In Phi Kappa Phi Forum (Vol. 89, No. 2, pp. 33-34). Honor Society of Phi Kappa Phi.

Voltmer, K. (2014). Making sense of press freedom: A comparison of journalists' perceptions of press freedom in Eastern Europe and East Asia. In Comparing Political Communication across Time and Space (pp. 157-171). Palgrave Macmillan, London. 